Vol. 19 No. 1, 2021
ISSN (online): 2746-4652
doi: 1 https://doi.org/10.33369/jwacana.v19i1.6577

\title{
THE PORTRAYAL OF FEMALE CHARACTER IN "LADY ELEANORE'S MANTLE” BY NATHANIEL HAWTHORNE
}

\author{
Putri Ramadhani \\ University of Muhammadiyah Bengkulu \\ Email:pr3756724@gmail.com
}

\begin{abstract}
This research concern with the analysis of female character in Lady Eleanore's Mantle by Nathaniel Hawthorne. The purpose of the research is to describe the female character of Lady Eleanore's Mantle by Nathaniel Hawthorne short stories by analyzing the main female characters to the development of the plot. This research using two methods, which are qualitative and descriptive. The problem of research is want to desribe the portrayal of female character in Lady Eleanore's Mantle. The woman is a beautiful, rich, and has high position in her community. Always get more attention and special treatment from other people and make her became to an arrogant girl. At the end, the woman get punishment and died tragically
\end{abstract}

Keywords : research, Lady Eleanore, analysis, Jervase Helwyse, beautiful, arrogant, punishment, female character

\begin{abstract}
Abstrak
Penelitian ini membahas tentang analisis karakter wanita dalam Lady Eleanore's Mantle karya Nathaniel Hawthorne. Tujuan dari penelitian ini adalah untuk mendeskripsikan karakter wanita dalam cerita pendek Lady Eleanore's Mantle karya Nathaniel Hawthorne dengan menganalisis karakter wanita utama hingga perkembangan plot. Penelitian ini menggunakan dua metode, yaitu kualitatif dan deskriptif. Rumusan masalah penelitian ini adalah ingin mendeskripsikan penggambaran tokoh perempuan dalam Mantel Lady Eleanore. Wanita itu cantik, kaya, dan memiliki posisi tinggi di komunitasnya. Selalu mendapatkan perhatian dan perlakuan khusus dari orang lain dan membuatnya menjadi gadis yang sombong. Pada akhirnya, wanita itu mendapat hukuman dan meninggal secara tragis.
\end{abstract}

Kata kunci: penelitian, Lady Eleanore, analisis

\section{INTRODUCTION}

In my analysis I will analyze the main female character in Lady Eleanore's Mantle by Nathaniel Hawthorne. The woman's nature must be respected, because the woman is noble. But, if a woman is overly valued it will make her proud and arrogant. As we know, the female character is divided into 2 kinds, namely the protagonist and antagonist. In this paper, I focus on analysis the antagonist character of Lady Eleanore's Mantle by Nathaniel Hawthorne. The antagonist characters commonly, in a fictional story, are the opposition characters for the protagonists. The antagonists will be the ones that create a conflict of the story. However, there are some cases that the conflict is not created by an antagonist character individually, but by other factors such as accident, natural disaster, moral value, etc. These conflict causes that are not caused individually by a character are called antagonistic force (Altenbernd \& Lewis, 1966:59).

Lady Eleanore is a very beautiful and rich girl, and also has a high position in the community. Because of that, making Lady Eleanore become a proud and disparage figure of other people. But because of her arrogance at the end of the story, Lady Ele* anore died horribly because it caused the 
community left her alone. At the end of her death, when the lady Eleanore realized her mistake, Jervase Helwise (the young man who loved her but was underestimated by Lady Eleanore) met her but only to make Eleanore regret her mistakes in the past.

Lady eleanore's character here often happens around us. Beautiful, rich, and highly educated girls will usually arise when a person like that is treated special by the people around her. Because she felt that nothing would be equal to her level. Here it appears that the writer (Nathaniel Hawthorne) wants to deliver the nature of women which tends to occur a lot in society and the writer also says that the end of being a proud person will not happy.

Allan Poe in Nurgiyanto in Regina Bernadette said short stories are interpreted as short readings that can be read once sitting in half to two hours, the genre has a single effect, characters, plots, and settings are limited, not diverse and not complex. The short story writer doesn't describe the ins and outs of the character's life as a whole, but only show important parts of the life of the character who functions to support the story which also aims to save the story writer because of the limited space available. And Turayev in Regina Bernadette argue short stories form narrative literary works that show a reflection of an episode in the life of a character.

The other statement, Stanton (2012:76) said short stories must be in solid form, in which the author creates character, their universe, and their actions simultaneously. But, in Kosasih (2004:431) argument, he said short stories are short essays in the form of prose. In short stories, a piece of the character's life is told, which is full of conflicts, touching or pleasent events, and contains the impression that the reader is not easily forgotten.

Acoording by Purba (2010:48), HB Jassin in his book namely "Tifa Poets and Regions" suggests that short stories are short stories (1977:69) Jassin further reveals that about this short story people may fight, but stories that are one hundred pages long are certainly it is not called a short story and indeed there is no such short story. A story that is ten or twenty pages long can still be called a short story but there are also short stories that are only one page long.

\section{Female character}

W.B. Saunders, (1977:126) explains that the characters are real and distinct properties shown by individuals, a number of attributes that can be observed in individuals. But Gulo W, (1982:29) notes that the chracter is a personality in terms of ethical or moral standpoint, for example a person's honesty, usually having to do with the properties that are relatively fixed. Kamisa (1997:281) reveals that the character is a psychiatric traits, morals or character that distinguish one person from another, character, character. Character means to have character, has a personality. In dictionary female character is a woman who is admired for great or brave acts or fine qualities: the chief female character in a story, play, movie, etc.

\section{Portrayal}

In dictionary an actor's portrayal of a character in a play or film is the way that he or she plays the character. The portrayal of something in a book is the act of describing it may be showing it. A humiliation or estimation of someone or something in a work of art or literature.

\section{METHOD}

In this research using descriptive approach as the method. Descriptive method is used to describe the specific behavior of the main character, like happens in the environment. According by Whitney (1960:160) descriptive method is the search for facts with the right interpretation. The purpose of a descriptive method is to check a phenomenon that is happening at a specific place and time.

The analysis such of three different points of view. First, the focus is on the visual portrayal of the characters and the behavior of the character. Second, the focus here is on the language the characters themselves use and the language used about the characters, and the characters sociability, which examines whether the female characters talk to each other or not, and if they do, what it is that they talk about. Third, the portrayal of the charaters is analysed character's role.

From the method above, we can conclude the descriptive method as a research method. This method describes the problem or case that is showing based on available facts, specific, then investigated to solve the problem and get the conclusions.

\section{Analysis}


"Lady eleanore was remarkable for a harsh, unyielding pride, a haughty consciousness of her herefutary personal advantages, whuch made her almost incapable of control. (Lady Eleanore's Mantle : 1838, p.1).”

In this quotation above tells a girl who is very beautiful, rich, and has a high position in her community. And also, he was treated specifically from the people around her. That's why she became an arrogant person, considered others who had different status with her.

"Nay," answered Lady Eleanore playfully, but with more scorn than pity in her tone, "your Excellency shall not strike him. When men seek only to be trampled upon, it was a pity to deny them a favor so easily granted and so well deserved!". (Lady Eleanore's Mantle: 1838, p.2).

In this quotation show the conversation between Lady Elanore and the Governor. We also can see Lady Eleanore has bad attitude when she answers the other people's question. When answering there is no concoction of the words she says. There is always a mocking tone like disparaging others.

"He loved her-and her scorn has driven him mad."(Lady Eleanore's Mantle: 1838, p.3).

The day Lady Eleanore get a love statement from a young man named Jervase Helwyse. But because she has bad attitude when she talks, it makes the young man who loved her mad.

"But I tell you sir, I could well-nigh doubt the justice of the Heaven above us if no signal humilitation overtake this lady, who now treads so haughtily into yonder mansion. See, if the nature doesn't assert uts claims over her in some mode thay shall bring her level with the lowest!". (Lady Eleanore's Mantle: 1838, p.3).

In other day Jervase Helwyse and Doctor Clarke meet Captain Langford, and said his dislike Lady Eleanore so much. And the Doctor Clarke claims Lady Eleanore will get punished for all of her bad attitude which is her arrogance.

" Lady Eleanore Rochcliffe stood apart from the mob of guest, insulating herself within a small than to the general throng. (lady Eleanore's Mantle: 1838, p.4)."

A few days later after receiving atribute from the Governor, Lady Elenaore and The principal Gentry of the colony wa invited to a party. But when there, Lady Eleanore didn't join the others. She just wanted to gather with people she considered respectable.

"But, Lady Eleanore, I pray you to take one sip of this holy wine, and then to pass the goblet round among the guests. And this shall be asymbol that you have ot sought to withdraw yourself from the chain of human sympathies- which whoso would shake off must keep company with fallen angles." (Lady Eleanore's Mantle : 1838, p.5).

Suddenly when Lady Eleanore was sitting and closing her eyes, someone comes to Lady Eleanore offering drinks that are considered sacred, the man is Jervase Helwyse.

"Pray gentleman, do my poor admirer no harm, " said Lady Eleanore, with a faint and weary smile. "Take him out of my sight, if such be your pleasure; for I can find in my heart to do nothing but laugh at him!" (Lady Eleanore's Mantle : 1838, p.5).

But because it, made Lady Eleanore and Jervase Helwyse accused of stealing. finally Jervase is forced to leave the party because of Eleanore's request.

"Cast it from you! " Exclaimed Jervase Helwyse, clasping his hands in an agoncy of entreaty. "It may not yet be too late! Give the accursef garment to the flames!" (Lady Eleanore's : 1838, p.6).

When forced to leave the party, Jervase Helwyse asked Lady Eleanore to release and burn the robe she was wearing for her safety. But Lady Eleanore remained arrogant responding to Jervase's words. "Cast it from you! " Exclaimed Jervase Helwyse, clasping his hands in an agoncy of entreaty. "It may not yet be too late! Give the accursef garment to the flames!" (Lady Eleanore's : 1838, p.6).

Lady Eleanore, with a laugh of scorn, drew the rich files of the embroided mantle over her head, in such a fashion as to give a completely new aspect to her beautiful face, which- half 
hidden, belong to some being of mysterious character and purposes. (Lady Eleanore's Mantle : 1838, p.6).

But Lady Eleanore remained arrogant responding to Jervase's words. She thought Jervase's words had exceeded the limit, because he dared to order her.

He made no more resitance to the violent efforts of the gentleman and servants, who almost dragged him out of the apartment, and dismissed him roughly from the iron gate of the Province House... (Lady Eleanore's Mantle : 1838, p.6).

Because of his courage in Lady Eleanore, Jervase Helwyse was finally fired and expelled from Province House.

It had been traced back to a Lady's luxurious chamber- to the proudest of the proud- to her that was so delicate, and hardly owned herself og earthly mould- to the haughty one, who took her stand above human sympathies- to Lady Eleanore!. (Lady Eleanore's Mantle :1838, p.8).

One day the existence of eleanore was searched, and it was found that he was lying on his luxury bed in a weak state and suffering from a disease. the disease caused by the eleanore's arrogance began to spread outside.

This dark tale, whispered at first, was now bruited far and wide. The people raved against the Lady Eleanore, and cried out that her pride and scorn had evoked a fiend, and that, between them both, this monstrous evil had been born. (Lady Eleanore's Mantle: 1838, p.8).

Many people were angry and ridiculed Eleanore. they assumed that Eleanor's arrogance made their village affected by an epidemic, which originated from Mantle Eleanore. Because of that, the community insulted Lady Eleanore.

"All have fled from ger, "said the physician. "Why do you seek her now? I tell you, youth, her nurse fell death-stricken on the threshold of that fatal chamber. (Lady Eleanore's Mantle : 1838, p.9).

Hearing news about Lady Eleanore, Jervase Helwyse tried to find Lady Eleanore. And finally he found Lady Eleanore. Because of her illness, Lady Eleanore's trusted people had moved away from her.

O Jervase Helwyse, "I wrapped myself in PRIDE as in a MANTLE, and scorned the sympathies of nature; and therefore has nature made this wretched body the medium of a dreadful sympathy. You are avenged-they are all avenged- Nature is avenged-for I am

Eleanore Rochcliffe!". (Lady Eleanore's Mantle : 1838, p.10).

When they met, Lady Eleanore said to Jervase Helwyse she regretted all her pride in the past. and she has felt punished for every bad deed.

"Jervase Helwyse, waving the red flag of the pestilence. It was said that, from that very hour, the pestilence abated, as if its sway had some mysterious connection, from the first plague stroke to the last, with Lady Eleanore's Mantle. (Lady Eleanore's Mantle : 1838, p.10).

Finally, Lady Eleanore died, and was buried with her mantle. After that the epidemic subsided. Jervase Helwyse leads Lady Eleanore funeral while carrying a Red Flag.

\section{CONCLUSION}

This story explored the female society of our environment in our daily life. Where we often find that woman who are born beautiful get more attentionfrom people around. Beautiful women also get special treatment from people. Because of that in this story told that a beautiful woman who often gets more attention and special treatment from her environment makes her being a proud and arrogant girl. Here the author focusses on the female character. How politeness, how to talk to others is not implemented. Only because the woman was flattered she became she became arrogant to always be respected without having to respect others. And she finally got a punishment 
from this attitude. Before her death she spread an outbreak of rumors originating from the mantle she was wearing. The end of the story, this woman finally died with an outbreak of her illness.

\section{REFERENCES}

Wibowo, Muhammad Putra. An Analysis of Protagonist and And Antagonist Characters in Rowling's Harry Potter and the Deathly Hallows. Bandung: Universitas Pasundan. 2016.

SG, Andro Satrio. 15 Pengertian Cerpen Menurut Para Ahli. Event Hunter Indonesia. 2018.

Yana, Dwi. Definisi Karakter. Jakarta:Universitas Gunadarma. 2013.

Reinaldi, Bagus, Rukmana, Dedy, Triandaru, Ikhsan and friends. Qualitative and Quantitative Research. Manut Advertising. 2016.

123, Sarjana. Penelitian Kualitatif, Definisi Menurut Para Ahli. Sidoarjo:Stainim. 2017.

Tesis, Id. Pengertian dan Jenis Metode Deskriptif. Surabaya. 2016.

Nur, Dedy Rahman, An Analysis of the Feminist Characters in Kate Chopin's "The Awakening". Universitas Widya Gama Mahakam. 2017.

Oktapiani, Tika, Natsir, M, Setyowati, Ririn. Women's Language Features Found In Female Character's Utterances In The Devil Wears Prada Movie. Mulawarman University. 2017.

Rini, Serat Candra. Character Education Values of Female Character in Serat Candra Rini. Universitas Kebangsaan Malaysia. 2014.

Adeyemi, L. Portrayal of Woman Characters in Selected Contemporary Yoruba Novels in Nigeria. Ethiopia. 2009.

Putri, Katriza Andika. The Changes Of Image's Represented by Snow White Character in Mirror Mirror Movie. Universitas Brawijaya. 2013.

Kwatsha, Linda. The Portrayal of Single Woman Characters in Selected African Lyterary Texts. Nelson Mandela Metropolitan University. 2015.

Kumari, A. Gender Stereotyped Portrayal of Woman in the Media:Perception and Impact on Adolescent. Jaipur:IIS University, 2015.

Barli, Christian, Sili, Surya, Valientien, Nita Maya. Woman Portrayal in Patriarchal Society Through Female Main Characters in Zemecki's Beowulf Film. Universitas Mulawarman. 2007.

Patmarinanta, Annisa, Ernawati, Potjut. A Study on Characterization of the Main Character "The Fault in Our Stars". Banda Aceh:Syiah Kuala University. 2016. 